\title{
MACROZOOBENTHOS OF THE SHALLOW WATERS OF PECHORA BAY (SE BARENTS SEA)
}

\author{
Anna A. Gebruk ${ }^{1,2}$, Polina B. Borisova ${ }^{3}$, Milana A. Glebova ${ }^{2}$, Alexander B. Basin ${ }^{3}$, \\ Miloslav I. Simakov ${ }^{3}$, Nikolay V. Shabalin ${ }^{2}$, Vadim O. Mokievsky ${ }^{3}$ \\ ${ }^{1}$ University of Edinburgh, United Kingdom \\ e-mail:Anna.Gebruk@ed.ac.uk \\ ${ }^{2}$ Marine Research Centre of Lomonosov Moscow State University, Russia \\ ${ }^{3}$ Shirshov Institute of Oceanology of RAS, Russia
}

Received: 16.03.2019. Revised: 01.08.2019. Accepted: 02.08.2019.

\begin{abstract}
Macrozoobenthic communities provide vital ecosystem services including habitats and foraging resources for other species in all marine ecosystems. Although macrozoobenthos of deeper parts of the Pechora Sea (SE Barents Sea) have been studied in more detail, there is a lack of research in shallow waters of the Pechora Bay. The study area lies within the Nenetsky State Nature Reserve, established in 1997, to protect important breeding and moulting grounds of waterfowl. Macrozoobenthos provide key foraging resources for waterfowl in the nature reserve, however, there is a mismatch between ornithological and macrobenthic data. Eight stations were studied along the Russky Zavorot Peninsula in the Pechora Bay on a depth of 1.1-1.8 m within the near-shore zone of the Nenetsky State Nature Reserve in August 2016. A monodominant community of Limecola balthica with a biomass of $21.31 \pm 0.32 \mathrm{~g} / \mathrm{m}^{2}$ and 14 species in total was recorded across the area. The dominant species of the community correspond to those in the community of $L$. balthica recently described from the central estuarine part of the Pechora estuary. A low biomass and poor species richness in the L. balthica community support the earlier published results for the northern part of the bay and indicate the dependence of the community characteristics on environmental factors. The paucity of macrozoobenthos in the area is likely attributed to extreme environmental conditions including the following: (1) the water column freezes to the bottom during winter in the shallows of the Pechora estuary or (2) the freshwater flow spreads under the ice, severely impacting salinity. Hence the community is comprised of eurythermal and euryhaline forms and is reduced in biomass. It is unlikely that the shallows of the Russky Zavorot Peninsula play an important role as feeding grounds for benthic predators since a low in biomass barren community of a burrowing mollusc $L$. balthica does not provide enough foraging resources to feed stocks of waterfowl. The L. balthica-community could be used as an indicator of climate changes in the future - it is predicted that a reduction in sea ice volume will improve conditions for growth of $L$. balthica and may therefore lead to an increased body size and biomass of bivalves in the shallows.
\end{abstract}

Key words: Arctic, biomass, estuary, Limecola balthica, macrobenthic community

\section{Introduction}

The Arctic Ocean has one of the most sensitive to environmental changes ecosystems on Earth (Spiridonov et al., 2012). Declines in sea ice thickness in the Arctic Ocean, along with an increase in air temperature, ocean acidification and anthropogenic pressures from offshore industries lead to changes in the marine ecosystems of the Arctic regions (Kwok \& Rothrock, 2009). The benthic fauna is often used to observe contemporary changes in the environment, since various environmental factors including the availability of organic matter and water temperature, as well as human activities, have direct impact on biomass and the composition of macrozoobenthos assemblages (Denisenko et al., 2003; Hinz et al., 2009). Recent publications revealed that benthic invertebrates also tend to ingest and accumulate microplastics from the water column (Courtene-Jones et al., 2017; La Beur et al., 2019). Hence, there is a need for expanding the current knowledge on macrobenthos, especially in the Arctic regions.

The Pechora Sea in the southeast (SE) basin of the Barents Sea is characterised by shallowness, a specific hydrological regime and by an intense offshore oil and gas exploration and production (Denisenko et al., 2003). The macrozoobenthos of the Pechora Sea accounts for approximately $35 \%$ of the benthic biodiversity in the Barents Sea and is generally well-described for the deeper waters; however, there is a lack of data for the near-shore areas (Dahle et al., 1998; Denisenko et al., 2003; Kucheruk et al., 2003; Sukhotin et al., 2008; Denisenko N. et al., 
2019). The macrozoobenthos of the Pechora Sea is characterised by a high variability in spatial distribution («mosaic pattern») caused by alterations of seafloor topography and sediment types. Presumably this is also applicable for the Pechora Bay (Dahle et al., 1998; Denisenko et al., 2003).

The study area is within the Pechora Bay, the large estuarine ecosystem that assures a huge proportion of continental runoff into the Barents Sea region. The Pechora Sea receives approximately 2.5 million tonnes of terrigenous sediments annually through the Pechora estuary (Dobrovolsky \& Zalogin, 1982). The Pechora Bay is characterised by a broad intertidal zone, with a tide height of 1.1-1.5 m (Byshev et al., 2003; Denisenko N. et al., 2019). The ice thickness in winter reaches 1.5 $\mathrm{m}$, freezing to the bottom of the shallow near-shore areas of the bay. Sediments in the bay are formed by clayey sands and are influenced by a continental runoff and permafrost abrasion (Denisenko N. et al., 2019). The latest review of macrozoobenthos of the Pechora Bay was by Denisenko N. et al. (2019) and was based on samples collected in 1995. Twentytwo sites from a depth range of between $5 \mathrm{~m}$ and 18 $\mathrm{m}$ were studied in the north-east and central areas of the bay. Overall, the most common was a typical estuarial assemblage with a strong dominance of Limecola balthica Linnaeus, 1758 (occurring at 9 of 22 sites). The L. balthica-community described by Denisenko N. et al. (2019) had a mean biomass of $130.3 \pm 64.8 \mathrm{~g} / \mathrm{m}^{2}$ and comprised 34 species in total.

The study area lies within the $1^{\text {st }}$ zone of the Nenetsky State Nature Reserve named «Pechora river estuary and a $2 \mathrm{~km}$ water territory surrounding the Russky Zavorot peninsula». The Nenetsky State Nature Reserve covers the River Pechora estuary and nearby islands. In total the state nature reserve covers an area of $3134 \mathrm{~km}^{2}$ of which more than a half $\left(1819 \mathrm{~km}^{2}\right)$ corresponds to marine areas (Nenetsky Zapovednik, 2019). To safeguard the area from rapidly developing industrial activities, a state nature reserve was established in 1997. The main aim of establishing the nature reserve was the protection of important habitats for waterfowl that stopover in shallow waters of the Pechora Sea during their migration from reproduction sites in West Siberia to variable wintering sites (Sukhotin et al., 2008). The Nenetsky State Nature Reserve provides nesting and feeding grounds, and forms part of the migration routes for 125 species of waterfowl and coastal birds. This includes species from the Red Data Book of the Russian Federation and IUCN Red List of threatened species, such as: the yellow-billed loon Gavia adamsii Gray, GR, 1859; Bewick's swan Cygnus columbianus bewickii Ord, 1815; the lesser white-fronted goose Anser albifrons Scopoli, 1769; the red-breasted goose Branta ruficollis Pallas, 1769 (IUCN, 2019).

Common species, such as the king eiders (Somateria spectabilis Linnaeus, 1758), form abundant flocks of up to tens of thousands of individuals to feed and molt before migrating to wintering grounds (Krasnov et al., 2002). Marine ducks, including king eiders, are specialised benthic feeders and their main prey items are bivalves (Sukhotin et al., 2008). Foraging macrobenthos were studied near the coasts of the Dolgy Island (Sukhotin et al., 2008; Denisenko S. et al., 2019). A mismatch between ornithological and macrobenthic data for the region was first noted by Sukhotin et al. (2008). However, macrobenthic assemblages have previously never been studied in the shallows of the continental shore of the Nenetsky State Nature Reserve. For the open-sea, sandy shallows (5-7 m deep) of the Medynsky Zavorot Peninsula, between the mouth of Pechora Bay and Dolgy Island, a community dominated by Limecola balthica (previously known as Macoma balthica Linnaeus, 1758) was described at several stations (Kucheruk et al., 2003). The biomass of benthos in this community was low (ca. $3 \mathrm{~g} / \mathrm{m}^{2}$ ) and species diversity was scarce (totally16 species and 1-8 species per sample), explained by a strong wave action.

Ultimately, there are no macrobenthic data available for continental shores of the Protected Area. The present study aimed at fulfilling the knowledge gap on shallow-water macrozoobenthos of the Nenetsky State Nature Reserve by describing macrozoobenthic assemblages of the Pechora Bay and comparing them to other Arctic estuarine communities. The results can be used as a baseline data for further conservation or spatial planning activities in the area.

\section{Material and Methods \\ Site description}

Benthic samples were collected between $24^{\text {th }}$ and $30^{\text {th }}$ August 2016 in the Nenetsky State Nature Reserve from the inner (southern) bay of the Russky Zavorot peninsula (Fig. 1A). The inner coastline of the Kuznetskaya inlet forms a shore of the Pechora Bay and is comprised of wetlands, protected from the waves and covered by vegetation (Fig. 1C). Tides on the inner shore are regular, semi-diurnal with a range of $1-1.5 \mathrm{~m}$. Bottom sediments were formed of homogeneous sand with silts across the whole sampling area (Appendix 1). 

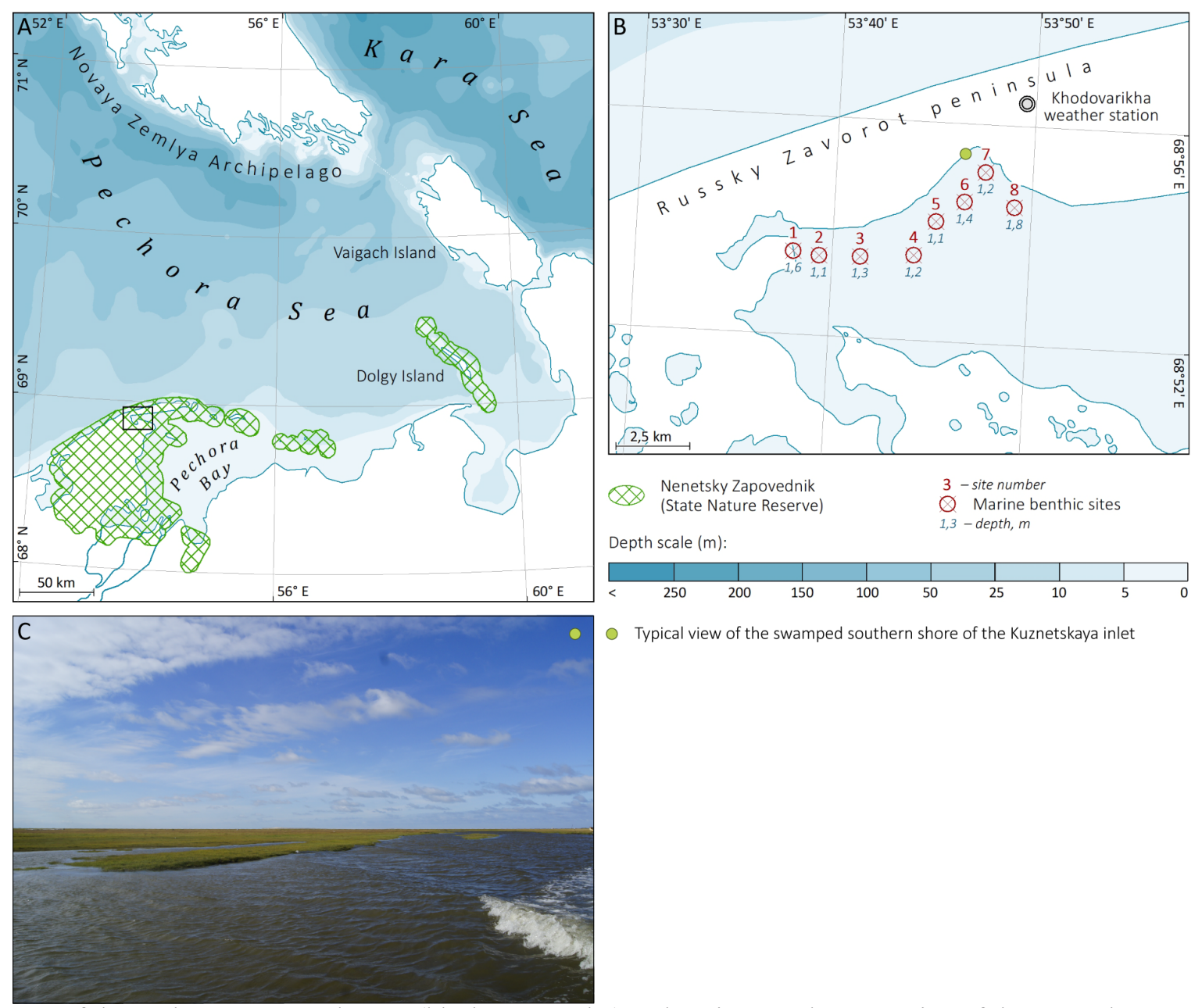

- Typical view of the swamped southern shore of the Kuznetskaya inlet

Fig. 1. Map of the study area. A: Study area (black rectangular) and territory under protection of the Nenetsky State Nature Reserve (green hatching). B: Sampling sites with bathymetry data shown for each site. C: Typical view of the swamped southern shore of the peninsula open to the Kuznetskaya inlet.

\section{Sampling}

Samples were taken at 8 stations in 3 replicates from each site in the depth range between $1.1 \mathrm{~m}$ to $1.8 \mathrm{~m}$ at low tide from a rubber motorboat with a hand shovel with capture volume of $0.05 \mathrm{~m}^{2}$. Sediments were washed over a mesh size of $0.5 \mathrm{~mm}$ with sea water, then pre-fixed with $4 \%$ formaldehyde.

In the laboratory, pre-fixed animals were manually sorted out of the organic debris of the samples for species identification, studied and re-fixed in $70 \%$ ethanol solution. Macrobenthic invertebrates were studied and photographed under a binocular microscope Leica165C and identified with the maximum level of certainty. All the species names were given in accordance to the World Register of Marine Species (WoRMS). For each sample identified taxa were counted and weighed on a Jewelry Scale ML-CF3 to mg, unidentified fragments were also weighed and recorded as «Varia».

Polychaeta fragments were counted both in anterior and posterior fragments and the bigger value chosen for each species. Bivalve molluscs were weighed with exoskeleton.

\section{Calculations}

Microsoft Excel and software PAST (version 2.17) were used for data analysis (Hammer et al., 2001; Hammer \& Harper, 2006). Non-transformed data were used.

Standard diversity indices were used to characterise diversity (dominance, Simpson index, Shannon index, Chao2), all calculations were performed using PAST software package (Hammer \& Harper, 2006).

Species accumulation curve or sample-based rarefaction was used to assess how samples represent biodiversity (species richness) predicted in the area. The predicted species richness $(\tilde{S})$ computed with Chao2-type estimator following Colwell et al. (2004), species accumulation curve was plotted in PAST with 95 percent confidence intervals (Hammer \& Harper, 2006):

$$
\widetilde{S}=S_{o b s}+\frac{(H-1) s_{1}^{2}}{2 H s_{1}}
$$

where $H$ - samples, $S_{\text {obs }}$ - the total number of observed species and $S_{1}-$ the number of species found in exactly one sample. 
Mean values \pm standard error are given for biomass and abundance.

Determination of macrozoobenthic assemblages was based on biomass values. Species with the largest contribution to biomass at each station were considered as dominants, second and third largest - as subdominants.

Classical hierarchical clustering based on paired group (UPGMA) algorithm and non-metric multidimensional scaling (MDS) both based on Bray-Curtis similarity index (Hammer \& Harper, 2006) were used to reveal whether the benthos across the sites formed distinct communities (groups). The Similarity percentage (SIMPER) was applied to assess taxa contribution to differences between the groups. The one-way analysis of similarities (ANOSIM) with Bonferroni-corrected p-values following Hammer \& Harper (2006) was used to estimate the significance of differences between the groups. The Pearson coefficient (r) was applied to assess correlations with environmental variables.

Maps were designed in ESRI ArcMap 10.4.1 using the standard GIS tools provided by the software. The reference coordinate system WGS84 and Universal Transverse Mercator projection (zone 40N) were used.

\section{Results}

A total of 14 taxa of benthic invertebrates were identified in 24 samples from 8 stations, 12 taxa identified to species level (Table 1). The fauna was mainly comprised of crustaceans ( 5 species), polychaetes ( 4 species) and bivalves (3 species), and with a single species of Priapulida and Insecta. Bivalves were the dominant group in both total biomass and abundance. The mean biomass of the macrobenthic invertebrates in the area was $21.31 \pm 0.32 \mathrm{~g} / \mathrm{m}^{2}$ and the mean abundance was $2131 \pm 1825$ individuals per $\mathrm{m}^{2}\left(\mathrm{ind} / \mathrm{m}^{2}\right)$. Primary data on abundance, biomass and number of species per sample are presented in Appendix 1. A taxonomic matrix of species with images of the specimens is in Appendix 2.

The Shannon diversity was low $\left(\mathrm{H}^{\prime}=1.26\right)$, macrozoobenthos was represented by a small number of taxa with a few individuals and astrong dominance of one species (Table 2). The predicted number of species was the same as discovered (Chao-2 richness $=14.19$ ). The biodiversity was represented close to equally between the stations: four species had $100 \%$ occurrence in the study area, and only one species had $<20 \%$ occurrence (Table 1 ).

The species accumulation curve approached the plateau at the level of 7 stations, reaching 14 species (Fig. 2). The discovered diversity of macrozoobenthos was therefore fully representative for the area.

The hierarchical clustering and MDS plots showed three groups of stations in the study area (Fig. 3). Group A consisted of stations 5, 7 and 8; group B included stations 2, 3 and 6; and station 1 formed a separate group.

ANOSIM analysis showed statistically significant difference between group A and B (Table 3, p <0.05).

Table 1. Species composition of macrozoobenthos and mean values of biomass $\left(\mathrm{g} / \mathrm{m}^{2}\right)$ and abundance (ind. $\left./ \mathrm{m}^{2}\right)$ of each species in the study area in 2016

\begin{tabular}{|c|c|c|c|c|c|}
\hline $\begin{array}{l}\text { Taxonomic } \\
\text { group }\end{array}$ & Species & $\begin{array}{l}\text { Mean biomass for the } \\
\text { study area, } g / \mathrm{m}^{2}\end{array}$ & $\begin{array}{l}\text { Mean abundance for } \\
\text { the study area, ind. } / \mathrm{m}^{2}\end{array}$ & $\begin{array}{l}\text { Frequency of oc- } \\
\text { currence across } \\
\text { sites }\end{array}$ & Habitats* \\
\hline Bivalvia & Cyrtodaria kurriana Dunker, 1861 & $0.18 \pm 0.004$ & $10.83 \pm 0.21$ & 0.5 & $\mathrm{~m}, \mathrm{~b}$ \\
\hline Bivalvia & Limecola balthica L.1758 & $17.29 \pm 0.19$ & $762.50 \pm 7.54$ & 1 & $\mathrm{~m}$ \\
\hline Bivalvia & Yoldia hyperborea Gould, 1841 & $2.87 \pm 0.09$ & $595.00 \pm 8.05$ & 1 & $\mathrm{~m}$ \\
\hline Crustacea & Saduria entomon Linnaeus, 1758 & $0.05 \pm 0.001$ & $2.500 \pm 0.07$ & 0.38 & $\mathrm{~m}, \mathrm{~b}$ \\
\hline Crustacea & Monoporeia affinis Lindstrum, 1855 & $0.006 \pm 0.001$ & $2.500 \pm 0.07$ & 0.25 & $\mathrm{~b}, \mathrm{f}$ \\
\hline Crustacea & Pontoporeia femorata Krшyer, 1842 & $0.001 \pm 0.001$ & $0.833 \pm 0.04$ & 0.16 & $\mathrm{~m}, \mathrm{~b}$ \\
\hline Crustacea & Monoculodes sp. Stimpson, 1853 & $0.003 \pm 0.001$ & $4.167 \pm 0.13$ & 0.38 & $\mathrm{~m}$ \\
\hline Crustacea & Diastylis sulcata Calman, 1912 & $0.005 \pm 0.001$ & $6.667 \pm 0.13$ & 0.75 & $\mathrm{~m}, \mathrm{~b}$ \\
\hline Insecta & Chironomidae gen.sp. & $0.002 \pm 0.003$ & $1.667 \pm 0.06$ & 0.25 & $\mathrm{~m}$ \\
\hline Polychaeta & Eteone agg. flava Fabricius, 1780 & $0.09 \pm 0.001$ & $31.667 \pm 0.32$ & 1 & $\mathrm{~m}$ \\
\hline Polychaeta & Laonice cirrata M. Sars, 1851 & $0.001 \pm 0.001$ & $0.833 \pm 0.04$ & 0.13 & $\mathrm{~m}, \mathrm{~b}$ \\
\hline Polychaeta & Micronephthys minuta Thŭel, 1879 & $0.009 \pm 0.007$ & $6.667 \pm 0.09$ & 0.63 & $\mathrm{~m}$ \\
\hline Polychaeta & Spio armata Thulin, 1957 & $0.57 \pm 0.007$ & $686.667 \pm 7.39$ & 1 & $\mathrm{~m}$ \\
\hline Priapulida & $\begin{array}{l}\text { Halicryptus spinulosus von Siebold, } \\
1849\end{array}$ & $0.17 \pm 0.001$ & $1.667 \pm 0.06$ & 0.25 & $\mathrm{~m}$ \\
\hline
\end{tabular}

Note: *Typical habitats are presented according to WoRMS with corrections (Filatova \& Zenkevich, 1957; Zhirkov, 2001): $\mathrm{m}$ - marine, $\mathrm{b}$ - brackish, $\mathrm{f}-$ fresh. 
Table 2. Key characteristics of macrozoobenthic diversity in the study area: number of taxa, number of individuals, dominance, Simpson diversity, Shannon diversity, estimated species richness (Chao-2 metric)

\begin{tabular}{|l|c|}
\hline \multicolumn{1}{|c|}{ Diversity indices } & $\begin{array}{c}\text { Values of diversity } \\
\text { indices }\end{array}$ \\
\hline Taxa_S & 14 \\
\hline Individuals & 2537 \\
\hline Dominance_D & 0.3151 \\
\hline Simpson_1-D & 0.6849 \\
\hline Shannon_H & 1.262 \\
\hline Chao-2 & 14.19 \\
\hline
\end{tabular}

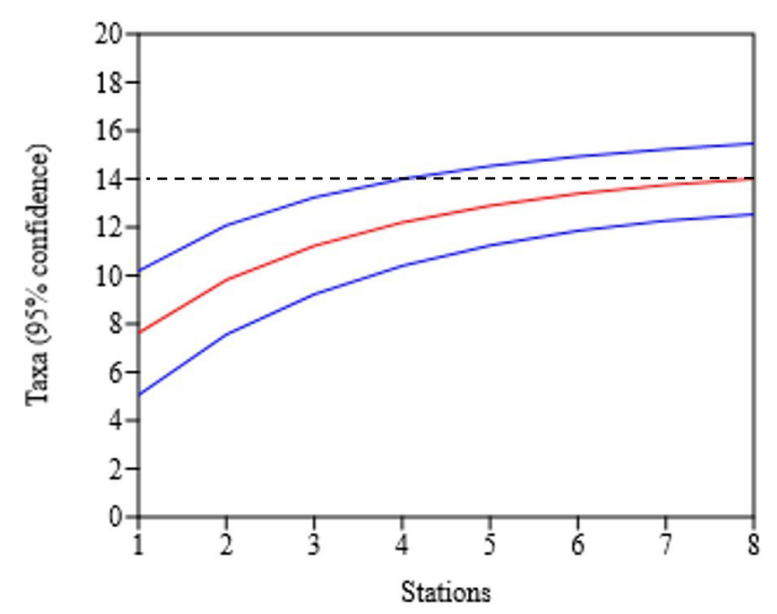

Fig. 2. Sample rarefaction (Mao's tau): red line - accumulated number of species, blue line $-95 \%$ confidential interval, black dotted line - number of species found in the samples.
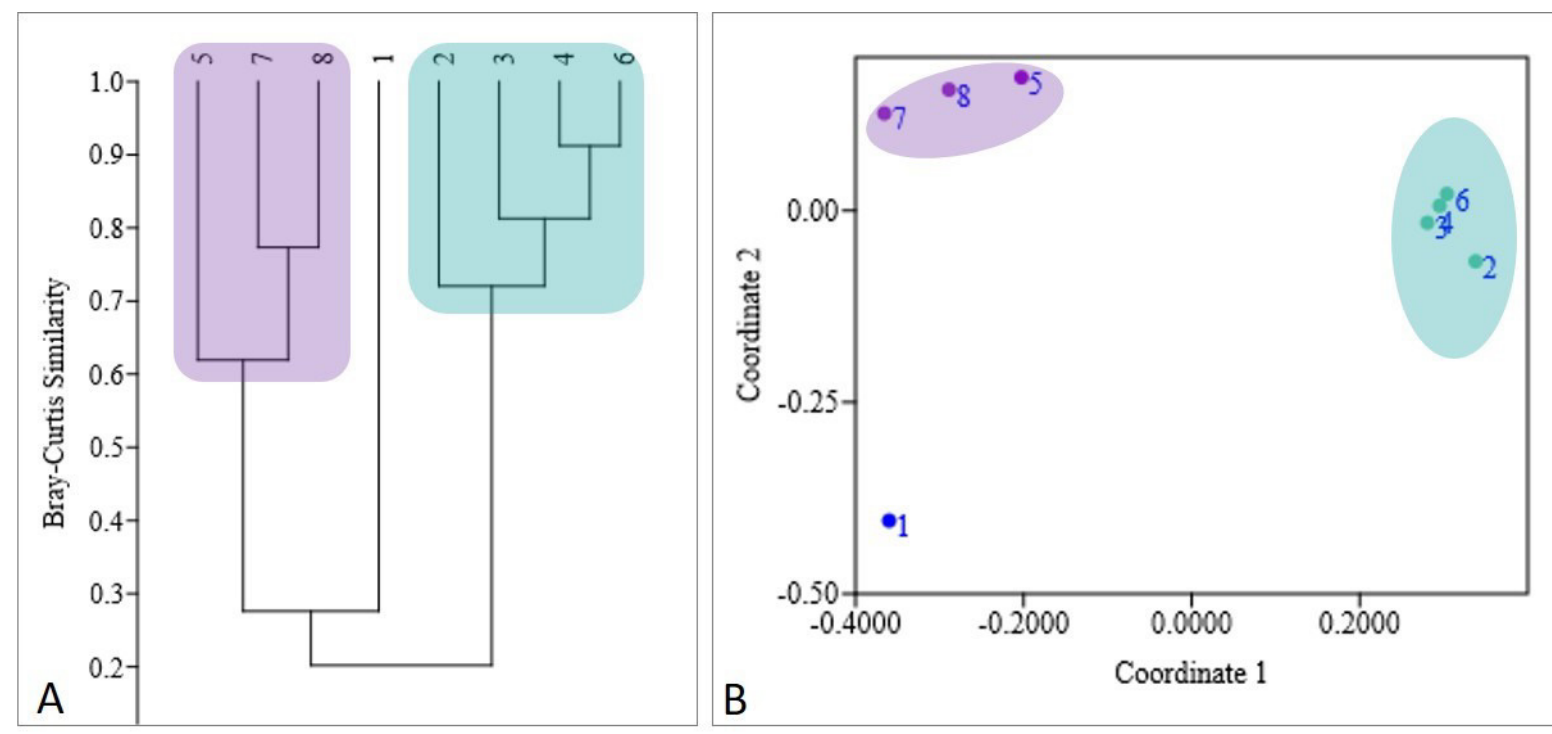

Fig. 3. Groups of stations in the study area determined by the hierarchical clustering (carried out on macrozoobenthic biomass data) (A) and MDS (B). Three groups can be seen: A - stations 5, 7 and 8, (purple shading); B - stations 2, 3, 4 and 6 (green shading); $\mathrm{C}-$ station 1.

Table 3. Pairwise comparison of groups of stations with ANOSIM analysis, Bonferroni-corrected p-values and Rvalues shown

\begin{tabular}{|c|c|}
\hline & Group B \\
\hline Group A & $\mathrm{p}=0.0283 ; \mathrm{R}=1$ \\
\hline
\end{tabular}

The variation in biomass of three species of bivalves (Limecola balthica, Yoldia hyperborea Gould, 1841 and Spio armata Thulin, 1957) assured difference between the stations as shown by SIMPER analysis (Table 4). The biomass of the bivalve $L$. balthica accounted for $83.7 \%$ contribution to the dissimilarity between the groups. Despite the statistical difference between the groups of stations, L. balthica remained the dominant species for all of the stations in the study area and differences were likely caused by natural variation in spatial distribution of the biomass of the common species. The macrozoobenthos in the study area was therefore formed by a monodominant community of L. balthica.
The species composition of each station and spatial distribution of the macrozoobenthos biomass $\left(\mathrm{g} / \mathrm{m}^{2}\right)$ across the study area are shown in Fig. 4. The biomass of macrozoobenthos per station had no correlation with the depth range $(\mathrm{r}=-0.45, \mathrm{p}=0.2)$.

\section{Discussion}

The macrozoobenthos of the Pechora Sea has been studied over nearly a hundred years (Zenkevich, 1927; Dahle et al., 1998; Denisenko S. et al., 2003, 2019; Kucheruk et al., 2003; Sukhotin et al., 2008; Denisenko N. et al., 2019). However, the vast majority of benthic surveys in this region were conducted on-board large research vessels at depths greater $\sim 10 \mathrm{~m}$. Hence there is a lack of macrozoobenthic data for near-shore and estuarine zones. This is also true for most of the Arctic zones, where shallow estuarine ecosystems are usually out of focus of big surveys. 
Table 4. Species contribution to dissimilarity between groups of stations produced by SIMPER analysis (only taxa with $>1 \%$ contribution shown)

\begin{tabular}{|l|c|c|c|c|c|}
\hline \multicolumn{1}{|c|}{ Taxon } & Average dissimilarity & Contribution \% & Cumulative \% & Group A & Group B \\
\hline Limecola balthica & 78.56 & 83.7 & 83.7 & 0.091 & 4.65 \\
\hline Yoldia hyperborea & 11.38 & 12.13 & 95.83 & 0.073 & 0.793 \\
\hline Spio armata & 1.902 & 2.027 & 97.85 & 0.005 & 0.113 \\
\hline
\end{tabular}
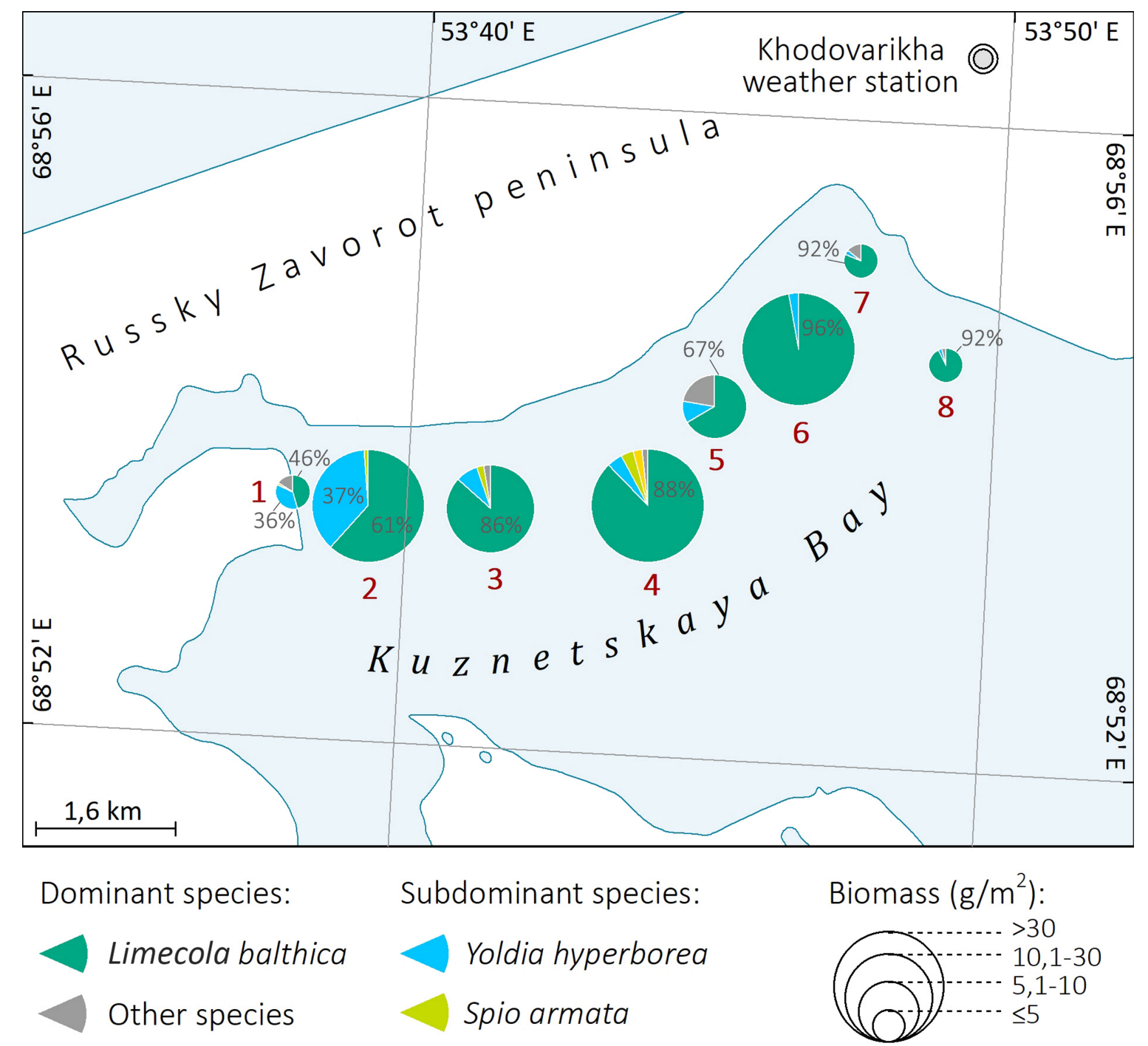

Subdominant species:

Biomass $\left(\mathrm{g} / \mathrm{m}^{2}\right)$ :

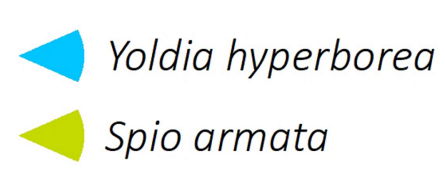

\section{Halicryptus spinulosus}

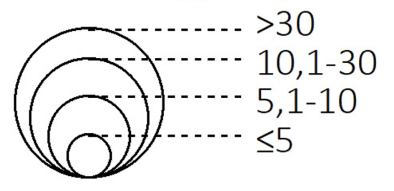

3 - site number

$\% 67$ - species contribution to total biomass per site (values $>10 \%$ labeled)

Fig. 4. Biomass $\left(\mathrm{g} / \mathrm{m}^{2}\right)$ and dominant species of invertebrates on the sampling sites.

The present study provides the first detailed report on macrozoobenthos of the continental shallows of the Nenetsky State Nature Reserve, although macrozoobenthos of the central and northern parts of the Pechora estuary were discussed in a recent publication by Denisenko N. et al. (2019). The authors sampled twenty estuarine sites in the Pechora Bay during the RV Geophysic cruise in spring 1995 and compared the Pechora Bay macrozoobenthos with that of the Ob bay in the Kara Sea (Denisenko et al., 1999). Recently Denisenko N. et al. (2019) reviewed their data.
Despite the small number of species found in the present study, the biodiversity of the macrozoobenthos was representative for the study area since it matched the predicted species richness (Chao$2=14.19, \mathrm{n}=14)$. Estuaries are typically characterised by lower biodiversity of macrobenthic invertebrates compared to marine environments. Ratios between marine, estuarine and freshwater species in the composition of estuarine macrozoobenthos typically depend on the salinity of a particular site (Whitfield et al., 2012). The River Pechora estuary is characterised as a mesohaline zone with low spe- 
cies richness (Denisenko N. et al., 2019). The species richness is affected more by the granulometric sediment structure than organic matter content of sediments or water salinity variations within the Pechora estuary (Denisenko N. et al., 2019). In the present study the fauna was comprised of marine species with a few brackish crustaceans. At least one brackish species was present at each station. Monoporeia affinis Lindstrum, 1855 and Saduria entomon Linnaeus, 1758, occurred with the frequency of 0.38 (recorded for stations 7 and 8) and 0.25 (stations 1, 2 and 8) respectively.

Macrobenthos communities in the study area were dominated by Limecola balthica with the mean biomass of $21.31 \pm 0.32 \mathrm{~g} / \mathrm{m}^{2}$ (varying from $1.33 \mathrm{~g} / \mathrm{m}^{2}$ on station 1 to $43.17 \mathrm{~g} / \mathrm{m}^{2}$ on station 2 ), and a total of 14 species. The observed differences in biomass between the stations were presumably a statistical artefact caused by natural variation in spatial distribution of biomass across the bay since the structure of dominance remained the same across the study area. Sediments also were the same across the study area supporting consistency of the benthic community. However, we acknowledge that an increasing research area would give a better understanding of the consistent patterns of species distribution across the bay.

In 1995, Denisenko N. et al. (2019) revealed five types of macrobenthic communities in the central and northern parts of the bay, as opposed to the only one observed in the present study. Of these five types, the community dominated by $L$. balthica was the most common overall and was characterised by the authors as typical for muddysand bottoms at depths of $5-10 \mathrm{~m}$ in the central part of the bay, with a strong dominance of $L$. balthica, a total of 34 species, moderate abundance and a biomass of $130.3 \pm 64.8 \mathrm{~g} / \mathrm{m}^{2}$ (Denisenko N. et al., 2019). As for diversity, the majority of species found in the present study were also present in Denisenko's L. balthica-community, except for the following: Chironomidae gen.sp., Laonice cirrata M. Sars, 1851, Spio armata and Yoldia hyperborea. All these species are typical for shallow water and often found in terrigenous coastal muds. The closest to our study area site sampled in 1995 was site 24 characterised by the $L$. balthica-community with a biomass of $21.9 \pm 1.8 \mathrm{~g} / \mathrm{m}^{2}$.

The study area is characterised by extreme environmental conditions for macrozoobenthos, e.g. an ice thickness up to $1.5 \mathrm{~m}$ with most habitats at depths 1-2 $\mathrm{m}$ freezing to the bottom. The inner shore of Russky Zavorot Peninsula is isolat- ed from wind-drift convection and is most probably impacted by the River Pechora run off. Furthermore, in semi-isolated near-shore areas in the Arctic, continental stock in winter forms a freshwater outflow that spreads under the ice, forming a layer of fresh water, forcing marine macrozoobenthos to move deeper into sublittoral zones, as was also described for the Canadian Arctic (Ellis, 1995). Therefore, the macrobenthic richness in the area is limited by ice thickness and freshwater impact and is comprised of eurythermal and euryhaline forms, tolerant to fluctuations in both temperature and salinity. The sea ice thickness and under-ice freshwater impact are common limitation factors for intertidal and upper sublittoral zones in the Arctic shallows (Mokievsky et al., 2016). Ultimately the community in the study area corresponds to the community with a dominance of $L$. balthica determined by Denisenko N. et al. (2019), though with lower richness and a biomass due to extreme conditions.

A further reduction of the Limecola-community was reported from the open shores of the Pechora Sea (Kucheruk et al., 2003). Biomass values in this area were even lower than in the present study, whilst among driving factors of macrobenthic distribution authors emphasised not the ice thickness or freshwater input, but wind waves that disturb sea bottom down to several meters depth as it has been shown for shallowness near Dolgy Island (Denisenko S. et al. 2019). As in the present study, the dominant species were also represented by abundant juveniles only (up to $1000 \mathrm{ind} / \mathrm{m}^{2}$ ) with a complete lack of adults.

Limecola balthica is an infaunal bivalve mollusc with a circumpolar distribution, common in the intertidal zones and estuaries, often dominant in soft bottom communities (Väinölä \& Varvio, 1989). In the Arctic region, L. balthica is dominant within the Pechora Bay as a relict species. A community with dominance of L. balthica and Cyrtodaria kurriana Dunker, 1861 was also described from the shallows of Baydara Bay (Kucheruk et al., 1998), but it was absent in typical Arctic estuaries, such as the Ob Bay in the Kara Sea in 1995 (Denisenko et al., 1999). Limecola balthica is evidently sensitive to the climate change, as was shown for stock from the western Wadden (North) Sea where an increase in water temperature resulted in a lower reproductive output and an earlier spawning period (Philippart et al., 2003).

Among the most common waterfowl of the Nenetsky State Nature Reserve is the king eider 
that feeds on macrobenthic invertebrates, often molluscs (Brun, 1971; Lovvorn et al., 2003; Merkel et al., 2007). It was shown for Dolgy Island in the Pechora Sea that marine ducks including the king eider were predominantly feeding on mussels Mytilus edulis Linnaeus, 1758, that were unreachable for traditional techniques of benthic research and therefore often underestimated (Sukhotin et al., 2008). Unlike the Dolgy Island research area, in the Russky Zavorot Peninsula any rock outcrops or fragments of mussel shells were not recorded during the present study. It is unlikely that the Limecola balthica-community in the shallows of Russky Zavorot peninsula provides enough foraging resources to sustain big stocks of waterfowl.

It has been repeatedly predicted in the literature that increasing temperatures in the Arctic will affect benthic communities, which could lead to changes in species distribution and interaction, allow the introduction of new species, and enable a decrease of arctic species alongside with an increase of boreal species in the composition of benthic fauna (Lambert et al., 2010; Josefson et al., 2013; Renaud et al., 2015). The Barents Sea has been identified as a hotspot for «atlantification» of seawater and the expansion of boreal species (Renaud et al., 2015; Vihtakari et al., 2018). It is likely that effects of climate change on the macrozoobenthos of the Pechora Bay will appear in the foreseeable future. In the study area, the thickness of sea ice is a key limitation factor for macrozoobenthos, therefore reduction of the sea ice volume would likely improve conditions and habitat availability for the L. balthica-community which leads to increasing the body size and biomass of molluscs inhabiting shallows. To achieve a broader understanding of the biomass trends of L. balthica stock in Nenetsky State Nature Reserve near-shore areas, the present study can be considered as a baseline with further regular observations required.

\section{Conclusions}

A community of macrobenthic invertebrates with a mean biomass of $21.31 \pm 0.3 \mathrm{~g} / \mathrm{m}^{2}$, strongly dominated by L. balthica, and comprising a total of 14 species, was described based on 8 stations in the shallows of the Russky Zavorot Peninsula at a depth of 1.1-1.8 $\mathrm{m}$ in August 2016. This is the first study of the benthos of the continental shallows of the Nenetsky State Nature Reserve. All studied sites were characterised by a muddy-sand substrate. The observed community represents a form reduced in richness and biomass of the $L$. balthica-community, described by Denisenko N. et al. (2019) from the central and northern parts of the River Pechora estuary. At the periphery of its distribution, the community is attributed to sea ice thickness and freshwater impact and is therefore comprised of eurythermal and euryhaline forms. Species occurring in the shallows but absent in deeper habitats described by Denisenko N. et al. (2019) included Chironomidae gen.sp., Laonice cirrata, Spio armata, and Yoldia hyperborea.

It is unlikely that the shallows of Russky Zavorot Peninsula play an important role as feeding grounds for benthic predators since a barren community of $L$. balthica does not produce enough foraging biomass. The state of the L. balthica-community can be used as an indicator of climate change in the future. We suggest that with a reduction in the volume of sea ice it is likely that conditions and habitat availability for the L. balthica-community will improve in the shallow waters, and this could lead to an increased size and biomass of bivalves. However, to gain a better understanding of $L$. balthica biomass dynamics in the Pechora Bay, more regular observations are required in both nearshore and open water areas.

The studies undertaken up until now within the marine borders of the Nenetsky Reserve are still rather scarce and do not cover the whole range of shallow water habitats. As for many other marine reserves in the Arctic, there is an urgent need for detailed habitat mapping and diversity estimations.

\section{Acknowledgements}

The authors express their gratitude to the administration and staff of the Nenetsky State Nature Reserve for enabling data collection. We gratefully acknowledge all involved in fieldwork (Evgeniy Snytnikov, Michael Borovskiy, Evgeniy Ezhelya - all are from Lomonosov Moscow State University) and processing of the samples (Milena Khutoryanskaya). We also thank Lea-Anne Henry and Nadia Jogee (Changing Oceans Group, University of Geosciences), Dr. Andrey Gebruk (Shirshov Institute of Oceanology of RAS) and anonymous reviewers for giving helpful feedback. The study is partly supported by the RFBR grant 18-05-60053.

\section{References}

Brun E.I. 1971 Predation of Chlamys islandica (O.F. Müller) by eiders Somateria spp. Astarte 4(1): 23-29.

Byshev V.I., Galerkin L.I., Galerkina N.L., Shcherbinin A.D. 2003. Dynamics and structure of water bodies. In: E.A. Romankevich, A.P. Lisitsin, M.E. Vinogradov (Eds.): The Pechora Sea: Integrated Research. Moscow: More. P. 93-116. [In Russian] 
Colwell R.K., Mao C.X., Chang J. 2004. Interpolating, extrapolating, and comparing incidence-based species accumulation curves. Ecology 85(10): 2717-2727. DOI: 10.1890/03-0557

Courtene-Jones W., Quinn B., Gary S.F., Mogg A.O., Narayanaswamy B.E. 2017. Microplastic pollution identified in deep-sea water and ingested by benthic invertebrates in the Rockall Trough, North Atlantic Ocean. Environmental Pollution 231(Pt 1): 271-280. DOI: 10.1016/j. envpol.2017.08.026

Dahle S., Denisenko S.G., Denisenko N.V., Cochrane S.J. 1998. Benthic fauna in the Pechora Sea. Sarsia 83(3): 183-210. DOI: 10.1080/00364827.1998.10413681

Denisenko N.V., Denisenko S.G., Lehtonen K.K. 2019. Distribution of macrozoobenthos in an Arctic estuary (Pechora Bay, SE Barents Sea) during the spring flood period. Polar Biology. DOI: 10.1007/s00300018-02452-6

Denisenko S., Sandler H., Denisenko N., Rachor E. 1999. Current state in two estuarine bays of the Barents and Kara Seas. ICES Journal of Marine Science 56: 187-193.

Denisenko S.G., Denisenko N.V., Lehtonen K.K., Andersin A.B., Laine A.O. 2003. Macrozoobenthos of the Pechora Sea (SE Barents Sea): community structure and spatial distribution in relation to environmental conditions. Marine Ecology Progress Series 258: 109-123. DOI: $10.3354 / \mathrm{meps} 258109$

Denisenko S.G., Denisenko N.V., Chaban E.M., Gagaev S.Y., Petryashov V.V., Zhuravleva N.E., Sukhotin A.A. 2019. The current status of the macrozoobenthos around the Atlantic walrus haul-outs in the Pechora Sea (SE Barents Sea). Polar Biology. DOI: 10.1007/ s00300-018-02455-3

Dobrovolsky A.D., Zalogin B.S. 1982. Seas of the USSR. Moscow: Moscow State University. 192 p. [In Russian]

Ellis D.V. 1995. Some observations on the shore fauna of Baffin Island. Arctic 8(4): 224-236. DOI: 10.14430/ $\operatorname{arctic} 3821$

Filatova Z.A., Zenkevich L.A. 1957. Quantitative distribution of the seafloor fauna of the Kara Sea. Proceedings of the All-Union Hydrobiological Society 8: 3-62. [In Russian]

Hammer Ø., Harper D.A.T. 2006. Paleontological Data Analysis. $1^{\text {st }} \mathrm{ed}$. Massachusetts: Wiley-Blackwell Publishing. P. 78-156.

Hammer Ø., Harper D.A.T., Ryan P.D. 2001. PAST: Paleontological statistics software package for education and data analysis. Palaeontologica Electronica 4(1): 9.

Hinz H., Prieto V., Kaiser M.J. 2009. Trawl disturbance on benthic communities: chronic effects and experimental predictions. Ecological Applications 19(3): 761-773. DOI: $10.1890 / 08-0351.1$

IUCN. 2019. The IUCN Red List of Threatened Species. Version 2018-2. Available from: http://www.iucnredlist.org

Josefson A.B., Mokievsky V., Bergmann M., Blicher M.E., Bluhm B., Cochrane S., Denisenko N.V., Hasemann C., Jørgensen L., Klages M., Schewe I., Sejr M.K., Soltwedel T., Wesławski J.M., Włodarska-Kowalczuk M.
2013. Marine invertebrates (Chapter 8). In: H. Meltofte (Ed.): Arctic Biodiversity Assessment. Status and Trends in Arctic Biodiversity. Conservation of Arctic Flora and Fauna. Akureyri: CAFF. P. 276-309.

Krasnov Yu., Goryaev Yu., Shavykin A., Nikolaeva N., Gavrilo M., Chernook V. 2002. Atlas of the Pechora Sea birds: distribution, abundance, dynamics, problems of protection. Apatity: Publishing Company of the Kola Branch of RAS. 164 p. [In Russian]

Kucheruk N.V., Mokievsky V.O., Denisov N.E. 1998. Macrobenthos of sea-shore zone in the southwestern part of the Kara Sea. Okeanologiya 38(1): 92-101. [In Russian]

Kucheruk N.V., Kotov A.V., Maksimova O.V., Pronina O.A., Sapozhnikov F.V., Malyh E.A. 2003. Benthos. In: E.A. Romankevich, A.P. Lisitsin, M.E. Vinogradov (Eds.): The Pechora Sea: Integrated Research. Moscow: More. P. 217-230. [In Russian]

Kwok R., Rothrock D.A. 2009. Decline in Arctic sea ice thickness from submarine and ICESat records: 19582008. Geophysical Research Letters 36(15): L15501. DOI: 10.1029/2009GL039035

La Beur L., Henry L.A., Kazanidis G., Hennige S., McDonald A., Shaver M., Roberts M. 2019. Baseline assessment of marine litter and microplastic ingestion by cold-water coral reef benthos at the East Mingulay Marine Protected Area (Sea of the Hebrides, western Scotland). Frontiers in Marine Science 6: 80. DOI: 10.3389/ fmars.2019.00080

Lambert G., Shenkar N., Swalla B.J. 2010. First Pacific record of the north Atlantic ascidian Molgula citrina bioinvasion or circumpolar distribution. Aquatic Invasions 5(4): 369-378. DOI: 10.3391/ai.2010.5.4.06

Lovvorn J.R., Richman S.E., Grebmeier J.M., Cooper L.W. 2003. Diet and body condition of spectacled eiders wintering in pack ice of the Bering Sea. Polar Biology 26(4): 259-267. DOI: 10.1007/s00300-003-0477-0

Merkel F.R., Mosbech A., Jamieson S.E., Falk K. 2007. The diet of king eiders wintering in Nuuk, Southwest Greenland, with reference to sympatric wintering common eiders. Polar Biology 30(12): 1593-1597. DOI: 10.1007/ s00300-007-0321-z

Mokievsky V.O., Dgebuadze P.Yu., Neretin N.Yu. 2016. On the vertical structure of intertidal zone of Babye More lagoon. Trudy of the White Sea Biological Station. Vol. 12. Moscow: KMK Scientific Press Ltd. P. 153-161. [In Russian]

Nenetsky Zapovednik. 2019. Nenetsky State Nature Reserve official website. Available from: http://www.nenetz.ru/. [In Russian]

Philippart C.J., van Aken H.M., Beukema J.J., Bos O.G., Cadée G.C., Dekker R. 2003. Climate-related changes in recruitment of the bivalve Macoma balthica. Limnology and Oceanography 48(6): 2171-2185. DOI: 10.4319/ lo.2003.48.6.2171

Renaud P.E., Sejr M.K., Bluhm B.A., Sirenko B., Ellingsen I.H. 2015. The future of Arctic benthos: Expansion, invasion, and biodiversity. Progress in Oceanography 139: 244-257. DOI: 10.1016/j.pocean.2015.07.007 
Spiridonov V., Gavrilo M., Krasnov Y., Makarov A., Nikolaeva N., Sergienko L., Popov A., Krasnova E. 2012. Toward the new role of marine and coastal protected areas in the arctic: the Russian case. In: F. Huettmann (Ed.): Protection of the Three Poles. Tokyo: Springer. P. 171202. DOI: 10.1007/978-4-431-54006-9_8

Sukhotin A.A., Krasnov Y.V., Galaktionov K.V. 2008. Subtidal populations of the blue mussel Mytilus edulis as key determinants of waterfowl flocks in the southeastern Barents Sea. Polar Biology 31(11): 1357-1363. DOI: $10.1007 / \mathrm{s} 00300-008-0474-4$

Väinölä R., Varvio S.L. 1989. Biosystematics of Macoma balthica in northwestern Europe. In: Genetics and Reproduction of Marine Organisms: Proceedings of $23^{\text {rd }}$ European Marine Biological Symposium. Fredensborg: Olsen \& Olsen. P. 309-316.
Vihtakari M., Welcker J., Moe B., Chastel O., Tartu S., Hop H., Bech C., Descamps S., Gabrielsen G.W. 2018. Black-legged kittiwakes as messengers of Atlantification in the Arctic. Scientific Reports 8(1): 1178. DOI: 10.1038/s41598-017-19118-8

Whitfield A.K., Elliott M., Basset A., Blaber S.J.M., West R.J. 2012. Paradigms in estuarine ecology-a review of the Remane diagram with a suggested revised model for estuaries. Estuarine, Coastal and Shelf Science 97: 78-90. DOI: 10.1016/j.ecss.2011.11.026

Zenkevich L.A. 1927. Quantitative estimation of the bottom fauna of the Pechora region of the Barents and White Seas. Proceedings of Floating Marine Scientific Institute 2(4): 3-64. [In Russian]

Zhirkov I.A. 2001. Polychaetes of the Arctic Ocean. Moscow: Yanus-K. 632 p. [In Russian]

Appendix 1. Primary data on abundance, biomass and number of species of macrozoobenthos collected in the Pechora Bay in 2016.

\begin{tabular}{|c|c|c|c|c|c|c|c|}
\hline \multirow{2}{*}{$\begin{array}{l}\text { Station- } \\
\text { sample }\end{array}$} & \multicolumn{2}{|c|}{ Co-ordinates } & \multirow{2}{*}{ Depth, m } & \multirow{2}{*}{$\begin{array}{l}\text { Abundance, } \\
\text { ind. } / \mathbf{m}^{2}\end{array}$} & \multirow{2}{*}{$\begin{array}{c}\text { Biomass, } \\
\text { g/m² }\end{array}$} & \multirow{2}{*}{ Number of species } & \multirow{2}{*}{ Sediments } \\
\hline & $\mathbf{N}$ & $\mathbf{E}$ & & & & & \\
\hline $1-1$ & \multirow{3}{*}{68.897778} & \multirow{3}{*}{53.634167} & \multirow{3}{*}{1.6} & 60 & 1.06 & 2 & Muddy sands \\
\hline $1-2$ & & & & 1080 & 2.02 & 8 & Muddy sands \\
\hline $1-3$ & & & & 640 & 0.92 & 2 & Muddy sands \\
\hline $2-1$ & \multirow{3}{*}{68.896111} & \multirow{3}{*}{53.659444} & \multirow{3}{*}{1.1} & 1160 & 0.92 & 4 & Muddy sands \\
\hline $2-2$ & & & & 4500 & 98.6 & 7 & Muddy sands \\
\hline $2-3$ & & & & 3940 & 29.98 & 6 & Muddy sands \\
\hline $3-1$ & \multirow{3}{*}{68.896667} & \multirow{3}{*}{53.695556} & \multirow{3}{*}{1.3} & 8400 & 10.68 & 5 & Muddy sands \\
\hline $3-2$ & & & & 2100 & 34.16 & 8 & Muddy sands \\
\hline $3-3$ & & & & 3140 & 43.82 & 6 & Muddy sands \\
\hline 4-1 & \multirow{3}{*}{68.898611} & \multirow{3}{*}{53.736944} & \multirow{3}{*}{1.2} & 1760 & 44.84 & 6 & Muddy sands \\
\hline $4-2$ & & & & 3380 & 33.78 & 8 & Muddy sands \\
\hline $4-3$ & & & & 3860 & 38.54 & 7 & Muddy sands \\
\hline $5-1$ & \multirow{3}{*}{68.905278} & \multirow{3}{*}{53.755278} & \multirow{3}{*}{1.1} & 1580 & 5.3 & 5 & Muddy sands \\
\hline $5-2$ & & & & 2900 & 13.52 & 5 & Muddy sands \\
\hline $5-3$ & & & & 2860 & 7.78 & 6 & Muddy sands \\
\hline $6-1$ & \multirow{3}{*}{68.915833} & \multirow{3}{*}{53.782778} & \multirow{3}{*}{1.4} & 1600 & 18.56 & 7 & Muddy sands \\
\hline $6-2$ & & & & 1960 & 62.44 & 7 & Muddy sands \\
\hline $6-3$ & & & & 1960 & 37.2 & 5 & Muddy sands \\
\hline $7-1$ & \multirow{3}{*}{68.920278} & \multirow{3}{*}{53.799167} & \multirow{3}{*}{1.2} & 560 & 2.86 & 3 & Muddy sands \\
\hline $7-1$ & & & & 680 & 3.4 & 6 & Muddy sands \\
\hline $7-3$ & & & & 1140 & 5.86 & 5 & Muddy sands \\
\hline $8-1$ & \multirow{3}{*}{68.914444} & \multirow{3}{*}{53.820000} & \multirow{3}{*}{1.8} & 840 & 5.58 & 5 & Muddy sands \\
\hline $8-2$ & & & & 620 & 2.84 & 5 & Muddy sands \\
\hline $8-3$ & & & & 420 & 6.56 & 3 & Muddy sands \\
\hline
\end{tabular}


Appendix 2. Taxonomic matrix of species with images taken under the binocular microscope.

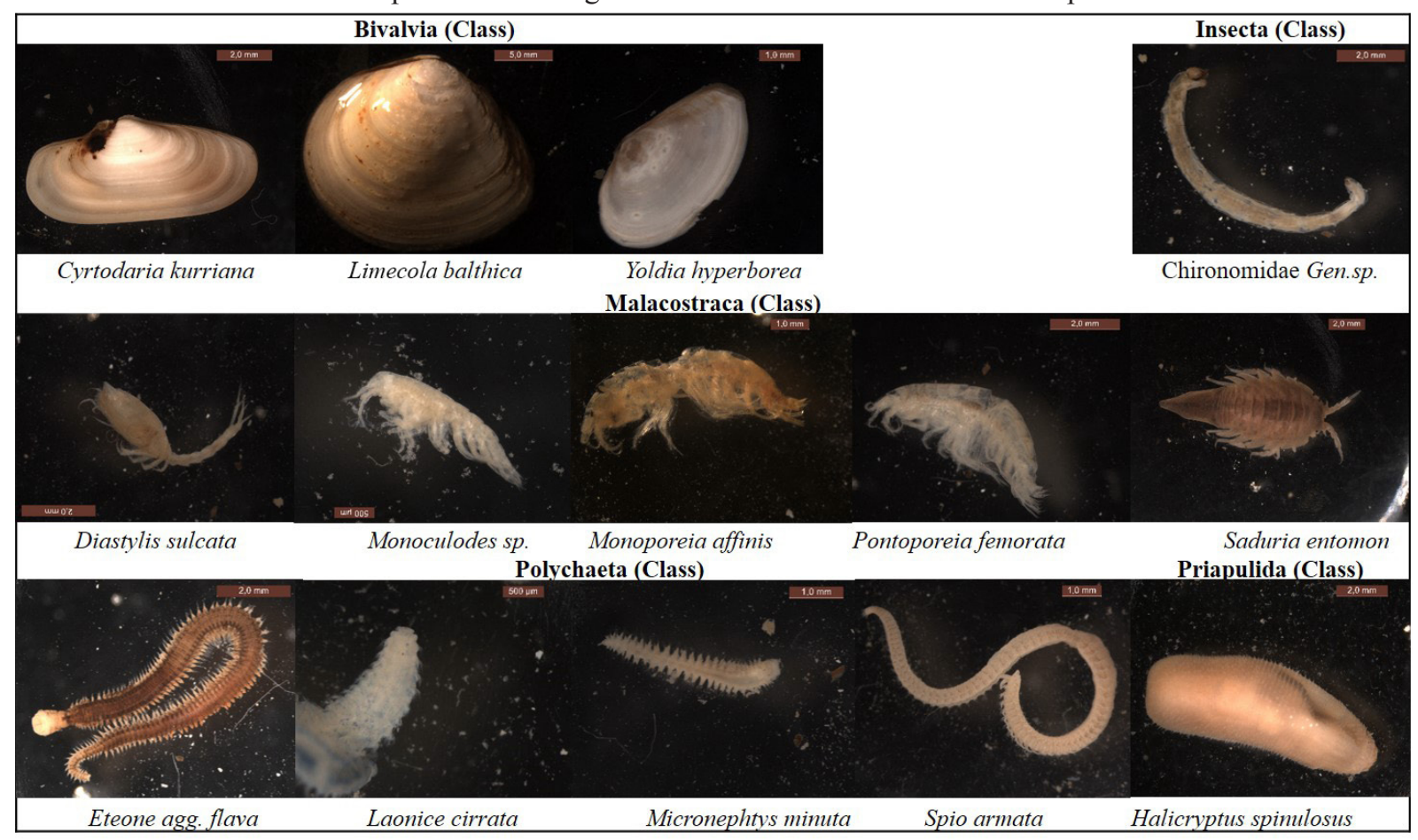

\title{
МАКРОЗООБЕНТОС МЕЛКОВОДИЙ ПЕЧОРСКОЙ ГУБЫ (ЮГО-ЗАПАД БАРЕНЦЕВА МОРЯ)
}

\author{
А. А. Гебрук ${ }^{1,2}$, П. Б. Борисова ${ }^{3}$, М. А. Глебова ${ }^{2}$, А. Б. Басин ${ }^{3}$, \\ М. И. Симаков ${ }^{3}$, Н. В. Шабалин ${ }^{2}$, В. О. Мокиевский ${ }^{3}$ \\ ${ }^{1}$ Университет Эдинбурга, Великобритания \\ e-mail:Anna.Gebruk@ed.ac.uk

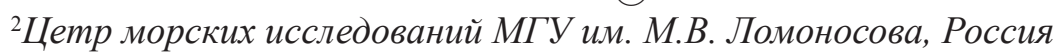 \\ ${ }^{3}$ Институт океанологии им. П.П. Ширшова РАН, Россия
}

\begin{abstract}
Сообщества макрозообентоса выполняют жизненно важные функции во всех морских экосистемах, в том числе формируя местообитания и пищевые ресурсы для других видов. Несмотря на то, что макрозообентос более глубоких участков Печорского моря (юго-западная часть Баренцева моря) в целом изучен достаточно детально, мелководные участки, в частности Печорская губа, изучены значительно хуже. Район исследований данной работы находился на территории Ненецкого государственного заповедника, основанного в 1997 г. с целью охраны ключевых районов кормления и линьки для морских птиц. Макрозообентос формирует основу пищевых ресурсов для морских птиц на территории Ненецкого заповедника, но в литературе наблюдается явный дисбаланс между количеством опубликованных орнитологических и гидробиологических данных. В данной работе был исследован макрозообентос восьми станций, собранный в августе 2016 г. вдоль побережья полуострова Русский Заворот внутри охраняемых вод Ненецкого заповедника на глубине 1.1-1.8 м. Для всех станций описано монодоминантное сообщество Limecola balthica со средней биомассой $21.31 \pm 0.32$ г м $^{2}$ и 14 видами макрозообентоса. Доминантные виды описанного сообщества совпадают с сообществом L. balthica, недавно описанным в литературе для центральной части Печорской губы. Низкая биомасса и видовое разнообразие сообщества L. balthica в исследуемом районе соответствуют ранее полученным данным для северной части эстуария. Они подтверждают гипотезу зависимости состояния сообщества от условий среды. Бедность макрозообентоса в районе работ вероятно связана с экстремальными условиями обитания, включающими (1) промерзание грунта на этих глубинах зимой или (2) подледное распреснение за счет континентального стока. В связи с этим макрозообентос сформирован эвритермальными и эврихалинными видами и характеризуется пониженной биомассой. Маловероятно, что континентальные мелководья полуострова Русский Заворот играют значимую роль как кормовые угодья для бентосных хищников, поскольку бедное по видовому составу и биомассе сообщество L. balthica не формирует достаточной для морских птиц кормовой биомассы. Сообщество L. balthica может быть использовано в качестве индикатора дальнейших климатических изменений в акватории, поскольку можно предположить, что уменьшение толщины морского льда улучшит условия обитания и приведет к увеличению размеров и биомассы мелководных моллюсков.
\end{abstract}

Ключевые слова: Limecola balthica, Арктика, биомасса, макробентосные сообщества, эстуарий 